\title{
Solar Powered Desalination System for Life Boat
}

\author{
Sunil Prakash Rodrigues ${ }^{1}$, Nithin Joshuva ${ }^{2}$, Sathisha $\mathrm{KG}^{3}$, Chandra Jogi ${ }^{4}$, Dinesh $\mathbf{M}^{5}$ \\ ${ }^{1}$ Assistant professor, Dept. of Marine Engineering, Srinivas Institute of Technology, Mangaluru, India \\ ${ }^{2}$ Assistant professor, Dept. of Marine Engineering, Srinivas Institute of Technology, Mangaluru, India \\ ${ }^{3}$ Assistant professor, Dept. of Marine Engineering, Srinivas Institute of Technology, Mangaluru, India \\ ${ }^{4}$ Associate professor, Dept. of Marine Engineering, Srinivas Institute of Technology, Mangaluru, India \\ ${ }^{5}$ Student, Marine Engineering, Srinivas Institute of Technology, Mangaluru, India
}

Abstract - A solar powered desalination system is developed for Life boats that can purify water from nearly any source, a system that is relatively cheap, portable, and depends only on renewable solar energy. The motivation for this project is the limited availability of clean water in Life boat. As per the SOLAS, 1.5L of water is reserved/person for 3 days, which is not sufficient. The project goal is to efficiently produce clean water from solar energy conversion inside Life boat and to add the water kept inside the life boat. Distillation requires an energy input as heat, electricity and solar radiation can be the source of energy. When solar energy is used for this purpose, it is known as solar water desalination. Solar distillation is an attractive process to produce portable water using free of cost solar energy. This energy is used directly for evaporating water inside a device usually termed as 'solar still'. The use of solar thermal energy in seawater desalination application is implemented in the Life boats where there is specific regulation on drinking water. This desalination system provides fresh water in efficient way by using only solar energy.

Keywords -Desalination, Solar still, Life boat, SOLAS.

\section{INTRODUCTION}

Water is a basic necessity of man along with food and air. Fresh water resources usually available are rivers, lakes and underground water reservoirs. About $71 \%$ of the planet is covered in water, yet of all of that $96.5 \%$ of the planet's water is found in oceans, only $2.5 \%$ of the Earth's water is freshwater. Less than $1 \%$ of all freshwater is in rivers, lakes and the atmosphere. Desalination is one of many processes available for water purification, and sunlight is one of several forms of heat energy that can be used to power that process. To dispel a common belief, it is not necessary to boil water to distill it, simply elevating its temperature, short of boiling, will adequately increase the evaporation rate. In fact, although vigorous boiling hastens the distillation process it also can force unwanted residue into the distillate, defeating purification. Solar Distillation is by far most reliable, least costly method of $99.9 \%$ true purification of most types of contaminated water and also sea water. Especially in developing nations where water is scarce or too expensive, solar distillation is used to produce drinking water or to produce pure water for lead acid batteries, laboratories, hospitals and in producing commercial products such as rose water. Conventional boiling distillation consumes three kilowatts of energy for every gallon of water, while solar distillation uses only the free pure power of the sun. Expensive filtration and de-ionizing systems are even more expensive to purchase and use and will not totally purify the water by removing all contaminants.

As per the SOLAS (Safety of life at Sea) the life boat should have desalinator which is operated by manually or mechanically and water is kept in life boat is about 1.5litres per person for three days, which is not sufficient. So to add water to that small sized solar still is fabricated which can produce fresh water of about $420 \mathrm{ml}$ within seven hours of time i.e., from $10 \mathrm{am}$ to $5 \mathrm{pm}$, such that it can be retrofit to the life boat. The fabricated solar still model is working with only solar energy. The system contains square pyramid glass, copper pan of surface area $0.09 \mathrm{~m} 2$, heating coil, vacuum pump, condenser, battery, solar panel, seawater and fresh tanks, submersible water pump and other pipes and valves.

\section{II.EXPERIMENTAL SETUP}

Solar stills are called stills because they distill, or purify water. A solar still operates on the same principle as rainwater: evaporation and condensation. The water from the oceans evaporates, only to cool, condense, and return to earth as rain. When the water evaporates, it removes only pure water and leaves all contaminants behind. Solar stills mimic this natural process. The solar still as shown Fig. 1 consists of a top cover made of glass 
which is in pyramid like structure, with an interior surface made of a waterproof membrane that is oil paint coating. This interior surface uses a blackened material to improve absorption of the sun's rays. Water to be cleaned is poured into the still to partially fill the basin using submersible water pump. The glass cover allows the solar radiation (short-wave) to pass into the still, which is mostly absorbed by the blackened base and heating coil is used to heat the water in the basin. The water begins to heat up and the moisture content of the air trapped between the water surface and the glass cover increases. The base also radiates energy in the infra-red region (long-wave) which is reflected back into the still by the glass cover, trapping the solar energy inside the still (the "greenhouse" effect). The heated water evaporates from the basin and condenses on the inside of the glass cover. In this process, the salts and microbes that were in the original water are left behind.

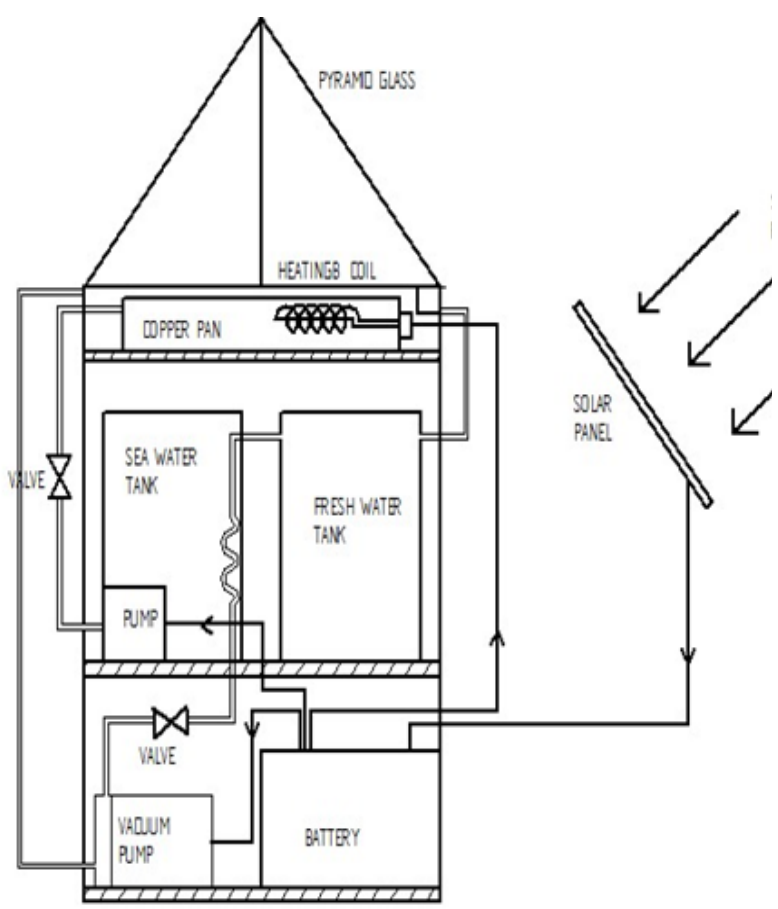

Fig 1: System Diagram of Solar Still

Condensed water trickles down the inclined glass cover to an interior condensate channel and out to a storage tank. The vacuum pump sucks the vapour inside the basin, hence it reduces the vapour pressure inside the system and the vapours are condensed in the heat exchanger inside the sea water tank Condensed water is collected in the fresh water tank. Battery is used to give supply for the submersible water pump, vacuum pump and heating coil. Switches are installed in the system to operate the electric components. The solar panel is used to charge the battery. The solar panel is inclined at angle 30degree facing south. Digital thermometers are used in the system to note down the readings of water and vapor temperatures inside the basin. The still is filled each morning or evening, and the total water production for the day is collected at that time. The still will continue to produce distillate after sundown until the water temperature cools down. Feed water should be added each day that roughly exceeds the distillate production to provide proper flushing of the basin water and to clean out excess salts left behind during the evaporation process.

In this work 'Pyramid square Glass Type' design is chosen as it can improve the productivity and increases the efficiency of the system. The normal type soda lime glass material of thickness $3 \mathrm{~mm}$ is chosen and made for the pyramid shape at an angle 25degree inclination, $10 \mathrm{~cm}$ height and base $40 \mathrm{~cm} \times 40 \mathrm{~cm}$. And the glasses are joined by applying silicone glue using silicone glue gun. The wooden basin is fabricated based on the size of the pyramid glass, for wooden basin, plywood material of thickness $12 \mathrm{~mm}$ is used and fabricated for the size of $10 \mathrm{~cm}$ height, $40 \mathrm{~cm}$ length and $40 \mathrm{~cm}$ breadth. At the top of wooden basin $0.5 \mathrm{~cm}$ groove is done for placing the pyramid glass on it and below that groove a condensate channel is installed.

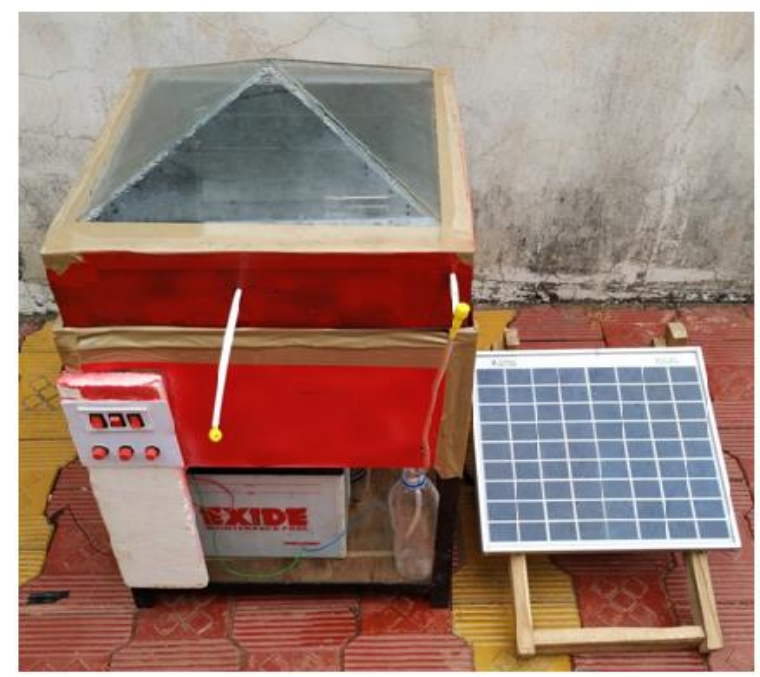

Fig 2: Experimental Setup

The condensate channel is made up of aluminum material and it is used to transfer the condensed water in the solar still to the fresh water tank. The basin is insulated with insulation material and upon that the copper which is painted black is placed. Then the heating coil is installed in the copper pan and supply, overflow, drain ports are connected with the pipes. 
Pyramid glass is placed and sealed on wooden basin. Solar still is mounted on the stand and other components like vacuum pump, submersible water pump, tanks and pipes are been connected. Battery and solar panel are installed and the wiring for electric components is done.

\section{RESULTS AND DISCUSSION}

The fabricated model is tested for the parameters like water temperature, vapor temperature, time and the output of the fresh water. The model is tested with three setup that are, only with solar still, solar still with vacuum pump and solar still with vacuum pump \& heating coil. And each setup is tested for three sunny days with the help of digital thermometers and weighing gauge for each hour from $10 \mathrm{am}$ to $5 \mathrm{pm}$. Average readings from three days are tabulated and graphs are plotted.

Table 1: Average Readings with Solar Still

\begin{tabular}{|c|c|c|c|}
\hline $\begin{array}{c}\text { TIME } \\
(\mathrm{hr} .)\end{array}$ & $\begin{array}{c}\text { SEA WATER } \\
\text { TEMPERATURE } \\
\left({ }^{\circ} \mathrm{C}\right)\end{array}$ & $\begin{array}{c}\text { VAPOUR } \\
\text { TEMPERATURE } \\
\left({ }^{\circ} \mathrm{C}\right)\end{array}$ & $\begin{array}{c}\text { FRESH WATER } \\
\text { OUTPUT } \\
(\mathbf{m l})\end{array}$ \\
\hline $10: 00 \mathrm{AM}$ & 35.8 & 51.9 & 0 \\
\hline $11: 00 \mathrm{AM}$ & 49.2 & 58 & 10 \\
\hline $12: 00 \mathrm{PM}$ & 53 & 59.5 & 20 \\
\hline $1: 00 \mathrm{PM}$ & 55.7 & 60 & 35 \\
\hline $2: 00 \mathrm{PM}$ & 49.8 & 54.4 & 49 \\
\hline $3: 00 \mathrm{PM}$ & 48.1 & 45.1 & 24 \\
\hline $4: 00 \mathrm{PM}$ & 43.3 & 38.6 & 20 \\
\hline $5: 00 \mathrm{PM}$ & 39.4 & 34.2 & 12 \\
\hline
\end{tabular}

Table no 1 . Shows the average readings of sea water temperature, vapor temperature and fresh water output with solar still for the three consecutive days from $10 \mathrm{am}$ to $5 \mathrm{pm}$

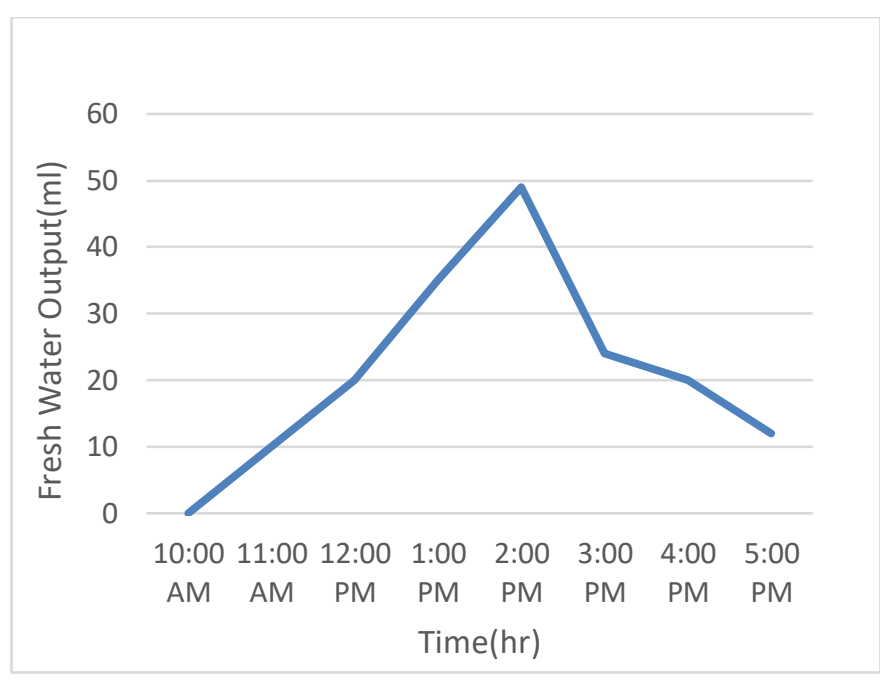

Fig 3: Fresh Water Output vs. Time for Solar Still only

Fig 3 shows the variation in the fresh water output with respect to time considering solar still only. It is found that the output is less initially but reaches maximum at $2 \mathrm{pm}$. This is because the ambient temperature at $1 \mathrm{pm}$ is at its peak and retains the heat until $2 \mathrm{pm}$ and after which it decreases.

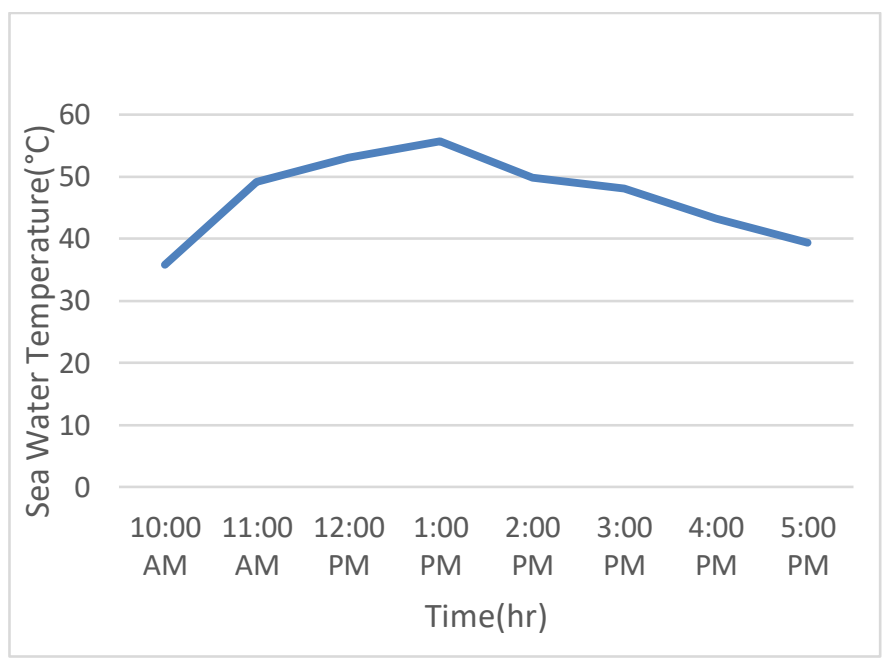

Fig 4: Sea Water Temperature vs. Time for Solar Still only

Fig. 4 shows the variation of sea water temperature with respect to time, for solar still only. It is noted that the sea water temperature gradually increases from 10am and it reaches the peak at $1 \mathrm{pm}$ as the solar intensity is maximum at $1 \mathrm{pm}$ and gradually decreases after $1 \mathrm{pm}$.

Table 2: Average Readings with Solar Still and Vacuum Pump 


\begin{tabular}{|c|c|c|c|}
\hline $\begin{array}{c}\text { TIME } \\
(\mathrm{hr} .)\end{array}$ & $\begin{array}{c}\text { SEA WATER } \\
\text { TEMPERATURE } \\
\left({ }^{\circ} \mathbf{C}\right)\end{array}$ & $\begin{array}{c}\text { VAPOUR } \\
\text { TEMPERATURE } \\
\left({ }^{\circ} \mathbf{C}\right)\end{array}$ & $\begin{array}{c}\text { FRESH } \\
\text { WATER } \\
\text { OUTPUT } \\
(\mathrm{ml})\end{array}$ \\
\hline $10: 00 \mathrm{AM}$ & 32 & 36 & 0 \\
\hline $11: 00 \mathrm{AM}$ & 53.4 & 54.5 & 22 \\
\hline $12: 00 \mathrm{PM}$ & 57.9 & 58.2 & 38 \\
\hline $1: 00 \mathrm{PM}$ & 60.5 & 70.2 & 46 \\
\hline $2: 00 \mathrm{PM}$ & 58.7 & 72.3 & 60 \\
\hline $3: 00 \mathrm{PM}$ & 56.5 & 68.1 & 42 \\
\hline $4: 00 \mathrm{PM}$ & 48.4 & 51.2 & 30 \\
\hline $5: 00 \mathrm{PM}$ & 38 & 44 & 18 \\
\hline
\end{tabular}

Table No. 2 shows the average readings of sea water temperature, vapor temperature and fresh water output with solar still and vacuum pump for the three consecutive days from 10am to $5 \mathrm{pm}$.

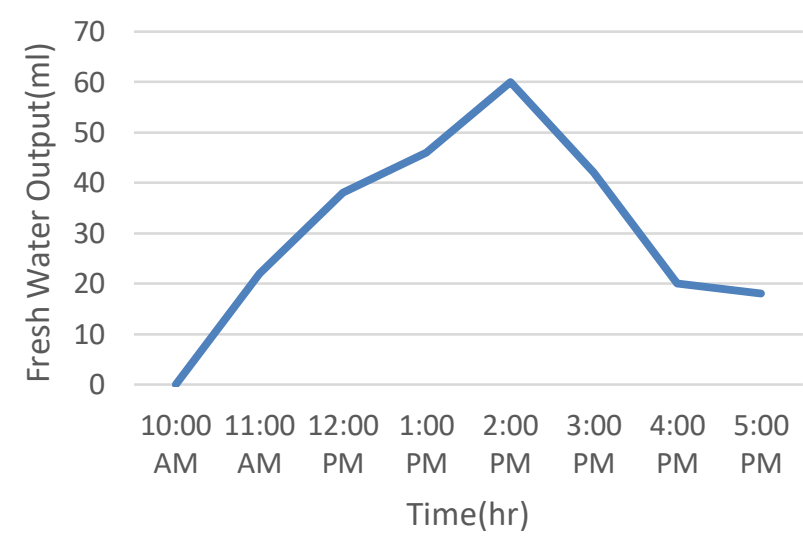

Fig 5: Graph of Fresh Water Output vs. Time for Solar Still and Vaccum Pump

Fig 5 shows the variation in the fresh water output with respect to time considering solar still with vacuum pump. It is found that the output is less initially but reaches maximum at $2 \mathrm{pm}$. This is because the ambient temperature at $1 \mathrm{pm}$ is at its peak and retains the heat until $2 \mathrm{pm}$ and after which it decreases.

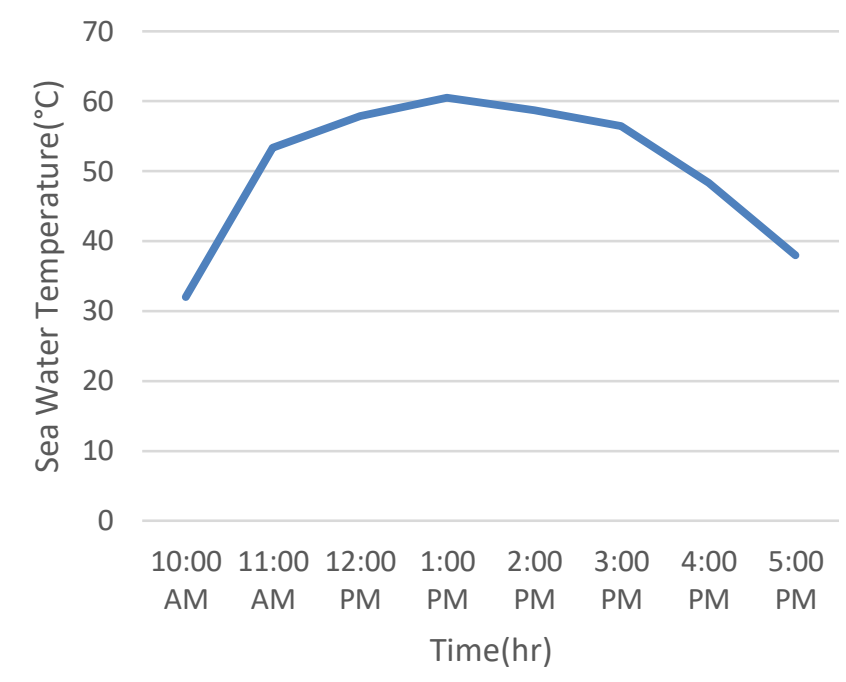

Fig 6: Sea Water Temperature vs. Time for Solar Still and Vaccum Pump

Fig. 6 shows the variation of sea water temperature with respect to time for solar still with vacuum pump. It is observed that the sea water temperature gradually increases from 10am and it reaches the peak at $1 \mathrm{pm}$, as the solar intensity is maximum at $1 \mathrm{pm}$ and thereafter the temperature gradually decreases.

Table 3: Average Readings with Solar Still, Vaccum Pump and Heating Coil

\begin{tabular}{|c|c|c|c|}
\hline $\begin{array}{c}\text { TIME } \\
(\mathrm{hr} .)\end{array}$ & $\begin{array}{c}\text { SEA WATER } \\
\text { TEMPERATURE } \\
\left({ }^{\circ} \mathrm{C}\right)\end{array}$ & $\begin{array}{c}\text { VAPOUR } \\
\text { TEMPERATURE } \\
\left({ }^{\circ} \mathrm{C}\right)\end{array}$ & $\begin{array}{c}\text { FRESH } \\
\text { WATER } \\
\text { OUTPUT } \\
(\mathrm{ml})\end{array}$ \\
\hline $10: 00 \mathrm{AM}$ & 34 & 42 & 0 \\
\hline $11: 00 \mathrm{AM}$ & 53 & 57 & 46 \\
\hline $12: 00 \mathrm{PM}$ & 60.6 & 66 & 62 \\
\hline $1: 00 \mathrm{PM}$ & 68.5 & 71.2 & 76 \\
\hline $2: 00 \mathrm{PM}$ & 66.8 & 67.8 & 92 \\
\hline $3: 00 \mathrm{PM}$ & 60.8 & 58.1 & 68 \\
\hline $4: 00 \mathrm{PM}$ & 55.6 & 50.7 & 44 \\
\hline $5: 00 \mathrm{PM}$ & 46.2 & 40 & 28 \\
\hline
\end{tabular}

Table No. 3 shows the average readings of sea water temperature, vapor temperature and fresh water output with solar still, vacuum pump and heating coil for the three consecutive days from $10 \mathrm{am}$ to $5 \mathrm{pm}$. 


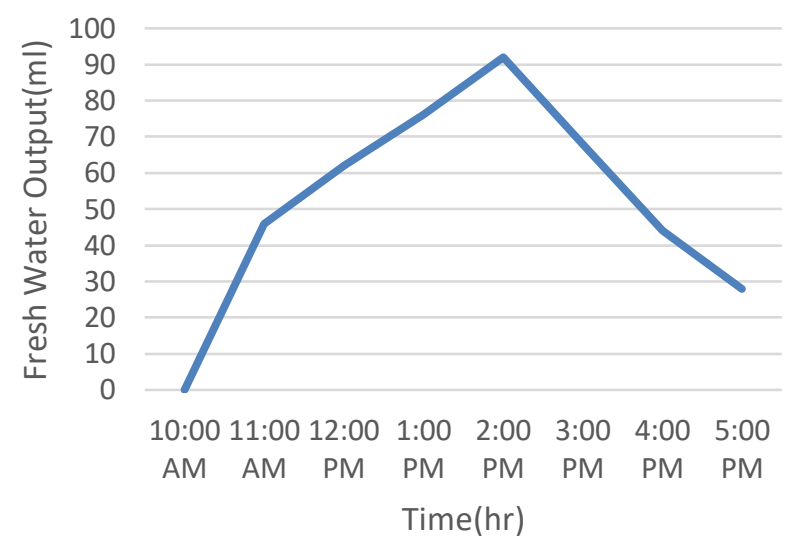

Fig 7: Fresh Water Output vs. Time for Solar Still Vaccum Pump and Heating Coil

Fig 7 shows the variation in the fresh water output with respect to time considering solar still with vacuum pump and heating coil. It is found that the output is less initially but reaches maximum at $2 \mathrm{pm}$. This is because the ambient temperature at $1 \mathrm{pm}$ is at its peak and retains the heat until $2 \mathrm{pm}$ and after which it decreases.

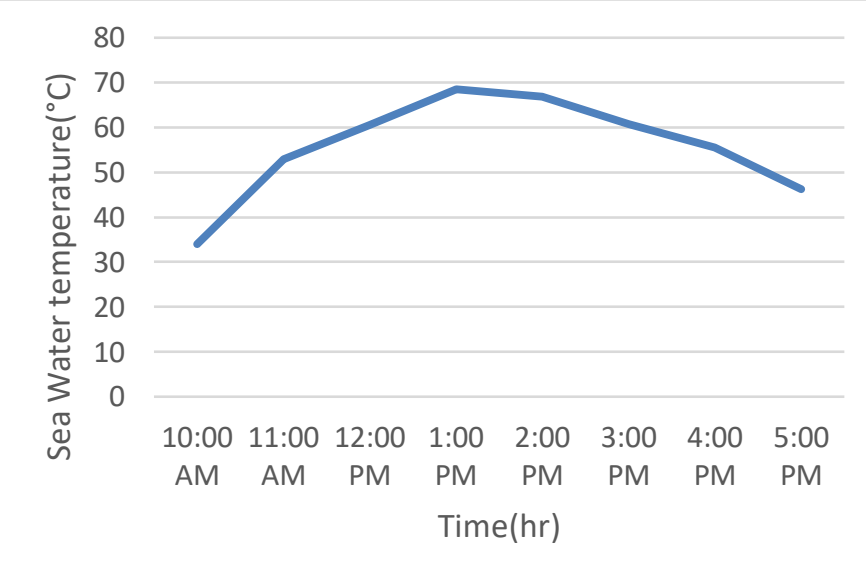

Fig 8: Sea Water Temperature vs. Time for Solar Still ,Vaccum Pump and Heating Coil

Fig 8 shows the variation of sea water temperature with respect to time for solar still with vacuum pump and heating coil. It is noted that the sea water temperature increases gradually from 10am and it reaches the peak at $1 \mathrm{pm}$ as the solar intensity is maximum at $1 \mathrm{pm}$ and gradually decreases thereafter.

Table 4: Parameters tested for the vaious water samples

\begin{tabular}{|c|c|c|c|}
\hline \multirow[t]{2}{*}{ Parameters } & \multicolumn{3}{|c|}{ Water Samples } \\
\hline & Sea water & Tap water & $\begin{array}{c}\text { Solar distilled } \\
\text { water }\end{array}$ \\
\hline $\mathrm{pH}$ & 8.23 & 6.40 & 6.63 \\
\hline Hardness in ppm & 9812 & 53 & 44 \\
\hline $\begin{array}{l}\text { Electrical conductivity } \\
\qquad \text { in } \Omega^{-1}\end{array}$ & 106.3 & 0.2 & 0.8 \\
\hline TDSin mgL ${ }^{-1}$ & 35000 & 67 & 11 \\
\hline $\begin{array}{c}\text { Dissolved Oxygen in } \\
\text { ppm }\end{array}$ & 12 & 9 & 6.8 \\
\hline
\end{tabular}

Table No. 4 contains some parameters which are tested in chemistry lab for the distilled water got from the solar still, tap water and the sea water. Samples are tested for $\mathrm{pH}$, Hardness, Electrical Conductivity, Total Dissolved Salts (TDS) and Dissolved Oxygen. The $\mathrm{pH}$ is found by using the $\mathrm{pH}$ meter. Hardness is found by hardness test (EDTA method). The Electrical Conductivity is found by Conductometer. Total Dissolved Salts is found by using TDS meter. The parameters of solar distilled water are nearer to the parameters of tap water, so it can be considered that the solar distilled water is safe to consume. The distilled water is drinkable however the taste is flatter and less flavorful than tap and bottled waters. This process removes minerals and impurities from the water. Some sources claim that drinking distilled water will help detoxify the body and improve health.

\section{CONCLUSION}

A small scale solar still is fabricated such that it can be retrofit to life boat. The system is tested for three consecutive days with solar still, with solar still and vacuum pump, with solar still, vacuum pump and heating coil. It is found that, solar still with heating coil and vacuum pump gave an output of $420 \mathrm{ml}$. The experimental efficiency of the solar still is calculated and it is found to be $22.70 \%$. The productivity of fresh water is less as compared to the persons in life boat. But it can be additional water to the water kept in the life boat. The solar distilled water obtained from the solar still is tested for some parameters in the chemistry lab like $\mathrm{pH}$, hardness, Electrical Conductivity, Total Dissolved Salts and dissolved oxygen and compared with tap water and seawater. The obtained water is in its pure form and if small volume of minerals and salts 
added can still improve the quality as per guidelines for drinking water.

\section{REFERENCES}

[1]. Lourdes Garcia Rodrigues, Sea water desalination driven by renewable energies, 20 May 2002.

[2].Jude O. Ozuomba, Emmanuel Anthony, Cornelius U. Ozuomba, Maureen C. Udoye, Fabrication and Characterization of A Slanting-Type Solar Water Distillation Kit, Science World Journal Vol 13(No 1) 2018.

[3]. H.M. Soliman, H.M. Elgohary, M. A. Abo Elmagd ,Brackish Water Desalination Using Solar Still with Built-in Heat Exchanger Coupled to Solar Collector.

[4]. T. Arunkumar, K. Vinothkumar, AmimulAhsan, R. Jayaprakash and Sanjay Kumar, Experimental Study on Various Solar Still Designs, 12 May 2012.

[5]. Moses KoilrajGnanadason, PalanisamySenthil Kumar, GopalSivaraman, Joseph Ebenezer Samuel Daniel, Design and Performance Analysis of a Modified Vacuum Single Basin Solar Still, 30 September 2011.

[6]. RavishankarSathyamurthy, S.A. El-Agouz, P.K. Nagarajan, J. Subramania,d, T. Arunkumar, D. Mageshbabu, B. Madhu, R. Bharathwaaj, N. Prakashe, A Review of integrating solar collectors to solar still, 07 December 2016

[7]. Chandrashekara M, AvadheshYadav, Water Desalination System Using Solar Heat, 30 August 2016

[8]. HimanshuManchanda, Mahesh Kumar Performance analysis of single basin solar distillation cum drying unit with parabolic reflector. 22 April 2017

[9]. A.E. Kabeel, S.A. El-Agouz, RavishankarSathyamurthy, Energy Analysis Of Single Slope Solar Still With Low Cost Energy Storage Material. 30 June 2018.

[10]. Ibrahim U. Haruna, MakshaYerima, Abalis D Pukuma, Ibrahim I. Sambo, Experimental investigation of the performance of basin type single slope solar still, March 2014 